\title{
Article
}

\section{Institutional voids, international learning effort and internationalization of emerging market new ventures}

Adomako, Samuel, Amankwah-Amoah, Joseph, Obeng Danquah, George, Danso, Albert and Donbesuur, Francis

Available at http://clok.uclan.ac.uk/28570/

Adomako, Samuel, Amankwah-Amoah, Joseph, Obeng Danquah, George, Danso, Albert and Donbesuur, Francis ORCID: 0000-0003-3793-802X (2019) Institutional voids, international learning effort and internationalization of emerging market new ventures. Journal of International Management, 25 (4). ISSN 1075-4253

It is advisable to refer to the publisher's version if you intend to cite from the work. http://dx.doi.org/10.1016/j.intman.2019.04.001

For more information about UCLan's research in this area go to http://www.uclan.ac.uk/researchgroups/ and search for <name of research Group>.

For information about Research generally at UCLan please go to http://www.uclan.ac.uk/research/

All outputs in CLoK are protected by Intellectual Property Rights law, including Copyright law. Copyright, IPR and Moral Rights for the works on this site are retained by the individual authors and/or other copyright owners. Terms and conditions for use of this material are defined in the policies page. 


\title{
Institutional voids, international learning effort and internationalization of emerging market new ventures
}

\author{
Samuel Adomako \\ School of Management, \\ University of Bradford, Bradford, \\ United Kingdom \\ Email: S.Adomako@bradford.ac.uk
}

\section{Joseph Amankwah-Amoah}

Kent Business School, University of Kent, UK.

Email: J.Amankwah-Amoah@kent.ac.uk

\section{George Obeng Danquah}

Newman University, Genners Lane, Birmingham B32 3NT

Email: G.ObengDankwah@staff.newman.ac.uk

\author{
Albert Danso* \\ Leicester Castle Business School, \\ De Montfort University, Leicester, UK. \\ Email: Albert.danso@dmu.ac.uk

\section{Francis Donbesuur} \\ Lancashire School of Business \\ University of Central Lancashire, Preston, UK \\ Email: fdonbesuur@uclan.ac.uk
}

*Corresponding author: Albert.danso@dmu.ac.uk 


\begin{abstract}
Much of the existing scholarly works portray institutional voids (IVs) in emerging economies as impeding forces against the development of new ventures. However, little attention has been paid to how such voids generate positive outcomes in emerging market new ventures. Drawing on the institutional theory, we propose IVs as crucial enablers of new venture internationalization. In addition, we investigate both how and when IVs enhance the degree to which new ventures internationalize by examining international learning effort (ILE) as a mediator and two domestic market environmental factors (i.e., environmental dynamism and competitive intensity) as important contingencies. We test our moderated mediation model using primary data gathered from 211 new ventures from Ghana. We found that ILE mediates the relationship between IVs and new venture internationalization and that both environmental dynamism and competitive intensity moderate the indirect relationship between home-country IVs and new venture internationalization. We discuss the theoretical and practical implications of this study.
\end{abstract}

Keywords: Learning effort; institutional voids; home market environment; new venture internationalization; Africa.

\title{
1. Introduction
}

The waves of liberalizations, privatizations and deregulations in the 1970s and early 1980s commencing in the West and spreading to the Global South ushered in a hyper-competitive environment for firms (Osei et al., 2018; Doganis, 2006; Dicken, 2007; Millward, 2005). In the wake of these globalization, transformations and subsequent market reforms, many firms are increasingly exploring foreign growth opportunities (Dai et al., 2014). However, differences in the national supportiveness and quality of the institutional environment remain a major problem facing firms (Tobias, et al., 2013) especially in Africa and unstable institutional environments, such as those often found in emerging economies (Bruton, et al., 2013; Stewart Jr, et al., 2008).

Broadly, one of the hallmarks of developing economies is the existence of institutional voids (IVs) (Garrone et al., 2018; de Lange, 2016; Khanna and Palepu, 2000a, 2010; North, 1990). However, market reforms across the continent since the 1980s under the Structural Adjustment Programs (SAPs) have ushered in new and more competitive environment for businesses. This has 
forced some firms to explore internationalization as strategic response (Amankwah-Amoah and Debrah, 2010). For example, Ghana has played a key role in not only championing the independence across the continent in the 1950s and 1960s, but also in advocating for market reforms since. Although many nations in Asia are classified as developing economies with IVs features, some have made greater leap forward in graduating from the so-called "third world" status to become fast growing emerging economies. Compared with African countries, nations in Asia such as China and India have made greater leap forward since the 1980s in terms of reducing vicious cycle of poverty, improving living standards and powering economic development (World Bank, 2011). Africa differs in terms of the values and norms which all influence entrepreneurs' investment decision. Broadly speaking, IVs such as weak intellectual property rights, red tape and bureaucracy are major characteristics of the business environment in both the African and Asian continents.

Indeed, institutional theory offers a useful theoretical milieu for understanding institutional challenges in developing and emerging economies (Wright et al., 2005; Stewart Jr, et al., 2008). Institutions are defined as "the rules of the game in a society or humanly devised constraints that shape human interaction" (North, 1990, p. 3). These encompass both formal and informal institutions (North, 1990; Scott, 1995). According to Mair and Marti (2009, p. 422), institutional voids (IVs) are said be present in an environment when "institutional arrangements that support markets are absent, weak, or fail to accomplish the role expected of them". Mair and Marti (2009) examined institutional voids to articulate how the institutional environment influences the entrepreneurial process. Given the evolution of this concept, institutional theory provides insights on how entrepreneurs within a country or region perceive themselves to be enabled or constrained by macro contingencies. IVs such as weak intellectual property rights, lack of transparency, red tape, bureaucracy, administrative delays, inadequate disclosure regime, corruption and political 
instability determine firms' ability to exploit and explore market opportunities (Acquaah, 2007; Khanna and Palepu, 2000a, 2000b, 2010). Firms situated in such institutionally stringent environments can be motivated to explore opportunities in foreign markets (Jones, 2012), but many are often confronted with problems such as lack of local market knowledge and expertise (Eriksson, et al., 1997). By acquiring and updating knowledge about foreign markets, firms would be better able to achieve strategic alignment (De Clercq, et al., 2012; Zaheer and Mosakowski, 1997).

While the internal business literature indicates that learning is crucial for firm success and the intensity of learning efforts can equip firms to improve their performance in foreign markets (Cohen and Levinthal, 1990; De Clercq, et al., 2014), there is a lack of knowledge related to how IVs influence firms' learning effort and their subsequent internationalization. In addition, there is the fundamental question: if institutional voids influence new ventures to do business outside the borders of their home country, under what condition does this happen? These issues are particularly important given that the literature on international business related to African businesses points to the strong influence of environmental factors on the internationalization behavior (see Ibeh, Wilson, and Chizema, 2012). As firms that embark on early internationalization tend to face high levels of risk and uncertainty, their effort to learn about the international market can help them understand institutional and competitive conditions in those markets (De Clercq, Sapienza, and Zhou, 2014; Eriksson, Johanson, Majkgard, and Sharma, 1997).

In addressing these gaps, we make two key contributions to international business and strategy research. First, our study deviates from much of the existing literature that has construed or equated IVs to negative effects for firms operating in the Global South (Mair and Marti, 2009; Meyer, et al., 2009; Ofori-Dankwa and Julian, 2013; Peng, et al., 2008). The existing literature has explored informal institutions in emerging economies and learning in internationalization (De 
Clercq et al., 2012; Schwens and Kabst, 2009); their analyses do not examine the underlying mechanisms through which IVs influence the new ventures' internationalization process. The current study, in contrast, sought to obtain evidence relevant to this question by investigating the potential mediating role of international learning efforts which have been found to be crucial in a firm's internationalization process (Sapienza, et al., 2005). Understanding the mechanisms through which firm-level variables such as a firm's efforts to learn from its foreign market(s) influence macro-level dependent variables of new venture internationalization has suggested as a crucial task for the field of international business (e.g., Sapienza, et al., 2005; De Clercq, et al., 2014). Second, although IVs have garnered a plethora of scholarly attention in the last two decades (Khanna and Palepu, 2000a, 2010; Mair, Marti and Ventresca, 2012) in organizational learning (Dau, 2013; Easterby-Smith and Lyles, 2011; Fiol and Lyles, 1985; Hyysalo, 2009; Lee and Yoon, 2015), there is still a theoretical deficit in our understanding of the conditions under which IVs drive learning effort for new ventures to do business beyond their domestic market. Our second contribution is to identify two such conditions.

Following a review of the literature on IVs and new venture formation, we present an analysis of our empirical setting and data sources. This is followed by an explication of our key findings on the effects of ILE. We conclude by setting out both the theoretical and practical implications of the study.

\section{Theory and hypotheses development}

\subsection{Institutional voids, ILE and internationalization}

Figure 1 presents our conceptual model and the relationship between IVs, ILE, new venture internationalization and the moderating effects of environmental dynamism and competitive intensity. In an era of increasingly volatile external environments, growth-seeking firms are 
increasingly required to explore the copious opportunities in emerging nations (Cavusgil et al., 2012; Hill and Hult, 2018). A substantial body of research has demonstrated the need to move on from the debate of whether institutions matter to the extent that institutions determine success or failure in new markets (Peng, 2004; Peng et al., 2008).

\section{Insert Figure 1 about here}

Given that local firms in emerging markets often faced threats stemming from institutional constraints, these constraints are likely to hamper their ability to be competitive (Hitt, Li and Worthington, 2005). A central contention is that weaker institutions or IVs can create unnecessary legal, political and economic challenges that perpetuate underdevelopment and impede business development. However, Mair and Marti (2009) hinted that IVs may represent an opportunity for social change. That is, IVs can trigger firms to internationalize through their learning efforts (Kalvet, et al., 2013). Firms commit scarce resources to learn about the home market ("domestic learning effort") and foreign markets ("international learning effort") to improve their competitiveness in international markets (Sapienza, et al., 2005). Accordingly, firms enhance their learning capacity by mobilizing and processing new external knowledge (Cohen and Levinthal, 1990; Easterby-Smith, et al., 2000). By undertaking ILE, market-seeking firms are more likely to insulate the potential effects of relationships between home-country IVs and new-venture internationalization. Some scholars have asserted that such firms may view constraints at home as an opportunity to learn and acquire new knowledge and/or use the home market as a "training ground" for foreign market expansion (see Hitt et al., 2005). That is, firms that perceive higher IVs tend to learn by accumulating superior knowledge to equip them to outcompete rivals (Grant, 1996; Kogut and Zander, 1992). Knowledge accumulations stem from learning from experience and learning from other organizations (Huber, 1991). 
By acquiring and assimilating knowledge from challenges of IVs in emerging markets, new ventures can embark on foreign market expansion to remain competitive (Schwens and Kabst, 2009; Zahra, et al., 2000). Through effective learning, firms can improve their resilience and ability to withstand institutional constraints. Based on these lines of thinking, we hypothesize that:

H1: The relationship between home-country IVs and new venture internationalization is mediated by ILE.

\subsection{The moderating role of environmental dynamism}

Environmental dynamism refers to the perceived speed of change in the external environment (Heyden et al., 2013). The dynamic environments are characterized by "rapid, discontinuous change in demand, competitors, technology, and/or regulations such that information is often inaccurate, unavailable, or obsolete" (Eisenhardt and Bourgeois, 1988, p. 816). Research has long established that environmental factors such as state of the economy, political instability and recession can nullify or dissipate a given market and resource advantage (Porter, 1991). Internationalization may be viewed as the viable strategy for emerging market firms confronted with unsurmountable IVs. Thus, the existence of IVs can motivate new ventures to innovate at incredible pace and scope.

To succeed in conditions of constant flux, firms need to learn to innovate to meet evolving customer and competitor demands (Miller and Friesen, 1982). In such conditions, the only option for firms is to learn and develop a knowledge reservoir about not only their domestic markets but also foreign ones (De Clercq et al., 2012). These advantages can equip firms to offset some of the negative effects stemming from liabilities created by IVs. These include limited access to scarce resources, limited prior history and limited customer base, which often constrain new firms' ability to access scarce resources and networks to improve their competitiveness (Bruderl and Schussler,

1990; Stinchcombe, 1965). By devoting greater levels of resources and expertise to exploring and 
exploiting foreign market opportunities, the intensity of a firm's learning effort is also increased (Ocasio, 1997). As such, more intense and repetitive processing creates conditions for firms and individuals to learn from such contexts (Sapienza et al., 2005). Nevertheless, new-venture firms tend to be agile in responding to environmental threats. By capitalizing on this lack of "old baggage" (Amankwah-Amoah, 2016), new-venture firms are better able to acquire and assimilate market knowledge at a faster pace (Autio et al., 2000).

Based on the above discussion, we argue that, when the environment is in a state of constant change and unpredictability, the indirect relationship between managerial perception of IVs and new-venture internationalization will be stronger. A major rationale is that in such conditions the basis for success may be predicated on firms' level of international venturing, enabling firms to take opportunities in the international market. Accordingly, we posit that:

H2a: Environmental dynamism moderates the indirect relationships between homecountry IVs and new venture internationalization in such a way that the indirect effect through ILE is stronger at higher levels of environmental dynamism.

\subsection{The moderating role of competitive intensity}

Prior studies show that firms' domestic-market competition affects the risk and uncertainty associated with their activities (Auh and Menguc, 2005). Given that entrepreneurs/CEOs control resources in new ventures (Lawrence, 1997), the decision to invest in international markets is affected by the level of competition. Competitive intensity denotes a situation of rivalry among

firms operating in the same industry where the behavior of a firm reflects the action of its industry rivals, which brings in unpredictable conditions (Ang, 2008; Auh and Menguc, 2005). This market condition is particularly pronounced in settings where formal institutions are weak (Gao et al., 2015) and firms adopt other means and strategies to overcome the liability of IVs. In this study, we integrate the institutional theory and the contingency philosophy to explain that, under 
conditions of higher competitor pressure, the effect of IVs on ILE would be strengthened, which will in turn translate into a higher degree of internationalization. First, the nature and extent of IVs in the home country mean that firms can only maximize their learning outcomes under certain domestic factors such as competitive intensity. During periods of high competitive, firms' behaviors are random, unpredictable and uncertain (Martin and Javal, 2016), which could reduce their growth opportunities. Second, during conditions of intense competition, firms engage in various learning and improvisation activities such as risk-taking, proactiveness and exploring new markets in order to be different and remain above their competitors (Cui et al., 2005; Zahra and Das, 1993). Thus, when competition within the industry is higher, it may then become the case that the basis for sustaining superior competitive advantage may be predicated on learning effort, which could enable new ventures to acquire superior knowledge in the international business arena. Further, most firms view their home country's IVs as an opportunity to learn and acquire new knowledge in other to circumvent the constraints of IVs, hence leading to an increase in their learning efforts. Accordingly, we argue that the combined effects of intense competition within the domestic market and IVs will ultimately amplify international ventures' learning efforts and activities. Accordingly, we contend that:

H2b: Domestic-market competition moderates the relationships between home-country IVs and new venture internationalization in such a way that the indirect effect through ILE is stronger at higher levels of competitive intensity.

\section{Research method}

\subsection{Study setting}

The hypotheses were tested using a sample of new ventures in Ghana, an emerging sub-Saharan African nation. Ghana was used as the research setting for several reasons. First, Ghana has received substantial attention in the popular business press regarding the success of its economic 
transformation and open-market policies (Acquaah, 2007; Leechor, 1994). This offers a unique context to investigate how Western industrialized theories relate to an emerging market setting. Second, Ghana is considered representative of sub-Saharan African economies (Julian and OforiDankwa, 2013). Third, recent literature has shown how most businesses in sub-Saharan Africa and particularly in Ghana have gained significant levels of internationalization due to their presence in neighboring international markets in the ECOWAS sub-region (Boso, et al., 2017). In effect, data from such a context will contribute significantly to the international business literature by exploring how and when firms could leverage the effects of IVs in their new venture internationalization process.

\subsection{Sample and data collection}

We followed previous studies (e.g., Adomako, et al., 2017; De Clercq et al., 2014) in selecting our sampling frame. First, we selected firms that engaged in international business activities including exporting, importing or activities involving cross-border business. This allowed us to capture firms that were involved in cross-border business activities or transactions.

Second, our sample included firms that internationalized within five years of their incorporation. This was done to exclude the process of incremental internationalization and to capture early internationalizing firms (Madsen and Servais, 1997). Third, we selected firms that were owned independently and non-subsidiary established businesses. This was done because company groups can transfer profits among the firms in the group and close subsidiaries for reasons other than poor performance (Wiklund and Shepherd, 2011). Fourth, our sample included ventures that were founded in 2007 or later. Given that our focus was on new ventures, we selected firms that were 10 years old or younger. Researchers disagree on what constitutes a new venture in entrepreneurship (Cardon and Kirk, 2015; Reynolds and Miller, 1992). We selected new 
ventures to capture various stages of the venture's development including those still at the opportunity identification stage.

From a total of 4,580 new ventures held in the Ghana Export Promotion Authority database, 755 ventures met the above sampling criteria. Subsequently, we approached the entrepreneurs of the 755 ventures in person with a hand-delivered questionnaire. Respondents were entrepreneurs (i.e., those who had been engaged in the start-up founding process).

To capture informant competency, each respondent was approached to provide information on a seven-point Likert scale ranging from $1=$ strongly disagree to $7=$ strongly agree. The informant competency assessed three main issues: (1) their knowledge about the issues under consideration, (2) accuracy of the information provided, and (3) confidence in providing answers to the questions (Morgan, Kaleka, and Katsikeas 2004). The informant competency test was administered as part of the main survey. Overall, we received 238 responses, yielding a 31.52\% response rate. However, 19 of the respondents provided incomplete answers to the competency test questions. These responses were discarded. Thus, we obtained 219 complete responses, representing a $29.01 \%$ response rate. The results of the informant competency test revealed a mean score of $6.53(\mathrm{SD}=0.56)$ for knowledge of issues, $6.44(\mathrm{SD}=0.53)$ for accuracy of responses, and $6.69(\mathrm{SD}=0.54)$ for confidence in answers.

For robustness check, we further approached the finance managers of the 219 firms for foreign sales and total sales figures to serve as an alternative measure of the degree of internationalization (Oesterle and Richta, 2013; Oesterle, et al., 2016). A total of 211 finance managers provided foreign and total sales figures, representing a 27.94\% response rate. Hence, we used $\mathrm{N}=211$ for the analyses.

The firms represented the following industrial sectors: mining and quarrying operators $=$ $28 \%$, processed food and beverages $=23 \%$, textiles and garments $=15 \%$; agroprocessing $=15 \%$, 
crafts and artisans $=9 \%$, engineering services $=3 \%$, financial services $=3 \%$, and security services=4: these sectors are representative of most developing economy industries. Therefore, most of the firms are in the manufacturing sector $=84 \%$, and a few are service sector firms $=16 \%$. On average the firms had been in business for nine years and they employed an average of eight full-time employees. The average annual turnover was US\$235,150.

To assess non-response bias, we compared early and late respondents in terms of entrepreneur's age, firm age, firm size and firm age at first internationalization using Pearson's chi-square test for discreet variables (Greenwood and Nikulin, 1996). We found no significant differences between the two groups. Hence, we concluded that non-response bias has no influence on our results (Armstrong and Overton, 1977; Rogelberg and Stanton, 2007).

\subsection{Measures}

Institutional voids. We used four items from Giachetti's (2016) study to capture the institutional voids $(\alpha=0.84)$. In all, four items were used to capture IVs. Specifically, we adapted only one item from the four measures. The wording of the following item was changed to reflect the Ghanaian business environment: "Underdeveloped education infrastructures and the need for intensive training of Chinse employees'. That is, instead of 'Chinese', we used 'Ghanaian' in the preceding statement. The rest of the three items were adopted with no changes to the wording. The scale taps managerial perception of the extent to which IVs are present in the business environment. The respondents were asked to indicate their rating on a seven-point scale with anchors ranging from $1=$ not at all to $7=$ to an extreme extent.

Environmental dynamism. We measure domestic-market environment dynamism $(\alpha=$ 0.90) by adopting a three-item scale developed by Miller and Friesen (1982). This scale tapped 
managerial perception of the degree of variation within the domestic-market environment. These items were on a seven-point Likert scale ranging from $1=$ not at all to $7=$ to an extreme extent.

Competitive intensity. The items measuring competitive intensity $(\alpha=0.89)$ were taken from Jansen et al. (2006). These items assessed managerial perception of degree of competition in the domestic environment. We captured the degree of competition on a seven-point Likert scale ranging from $1=$ not at all to $7=$ to an extreme extent.

International learning effort. We adopted the seven-item scale with anchors: $1=$ not at all and $7=$ to an extreme extent to measure ILE. This scale was adapted from De Clercq, et al., (2014) and it assessed the extent to which the venture embarks on activities to acquire new knowledge about foreign markets $(\alpha=0.88)$.

New venture internationalization. We utilized the four-item scale developed by Zahra et al. (2000) to capture new-venture internationalization $(\alpha=0.91)$. This scale tapped a venture's propensity to undertake international expansion activities. Accordingly, respondents were asked to respond on a seven-point scale ranging from $1=$ strongly disagree to $7=$ strongly agree, to determine the extent of their firms' internationalization intensity within the last two years.

Control variables. We included several control variables to account for their influence on the research model. Firm age was measured using the number of years the business has operated since its incorporation. Firm age was included as a control variable because it has the potential to influence a firm's international operations and performance (Zahra et al., 2000). Firm size has the potential to increase a firm's propensity to internationalize (Zahra et al., 2000). Accordingly, we measured firm size as the logarithm transformation of the number of full-time employees in the business. The entrepreneur's age was included as a control variable as it may show the level of his or her decision-making confidence (Adomako, et al., 2017). Hence, the entrepreneur's age was measured as the number of years since the entrepreneur was born. In addition, as the entrepreneur 
obtains more experience on the job, he or she gains significant international experience that may influence his or her decision-making process regarding internationalization (Oesterle, et al., 2016). The entrepreneur's international experience was measured as the number of years the entrepreneur has spent abroad during his or her education or professional career (Laufs, et al., 2016; Musteen, et al., 2010). Prior research has emphasized that industry differences influence a firm's degree of internationalization and its entry mode choice (e.g., Brouthers and Brouthers, 2003; Erramilli and Rao, 1993). In addition, it may be easier in some industries to adapt products than it is in other industries. Hence, industry type was captured with a dummy variable: $0=$ manufacturing; $1=$ service (Wang, 2008). Using a logarithm transformation to deal with skewness, we controlled for venture's age at first internationalization (De Clercq, et al., 2014). New ventures are constrained by limited financial resources which can hamper the degree to which business is conducted beyond the borders of their domestic market (Ripollés, et al., 2012; Zacharakis, 1997). As such, we controlled for financial resource availability by asking respondents to indicate the degree to which their firms have adequate financial resources to enter a foreign market. We adopted a four-item financial resource scale from Wiklund and Shepherd (2005).

\section{Insert Table 1 about here}

\section{Analyses}

\subsection{Common-method variance, reliability and validity assessment}

We minimized potential common-method variance by performing two tests. First, we used the approach suggested by Lindell and Whitney (2001) by introducing a marker variable that is not conceptually related to any of the study's constructs. In this study, we identified "foreign employees in the venture's workforce" as our marker variable which is theoretically unrelated to any of the constructs in the model tested. We found that correlation between the market variable 
item and the dependent variable is non-significant $(\mathrm{r}=-0.02 ; \mathrm{p}>0.10)$. In addition, we found nonsignificant correlations between the marker variable and other constructs in our model, ranging from 0.00 to 0.05 . Furthermore, a $95 \%$ sensitivity analysis revealed that partial correlations between our hypothesized constructs were significant even after we had taken account of the effect of common-method variance. This indicates that common-method variance does not substantially influence the relationships specified in our study.

Second, we utilized the approach advanced by Williams, Cote and Buckley (1989) and estimated a full-measurement model, in which the same model was re-estimated when an uncorrelated method factor was added. We inspected measurement model quality by examining three fit heuristics, factor loadings and correlations. The fit heuristics inspected were the root mean square error of approximation (RMSEA), the comparative fit index (CFI) and the standardized root mean square residual (SRMR). Confidence in model fit is established when the RMSEA is less than 0.08, the CFI is larger than 0.90 and the SMMR is less than 0.10 (Vandenberg and Lance, 2000). In this study, the inspected fit heuristics $(\mathrm{RMSEA}=0.06, \mathrm{SRMR}=0.07, \mathrm{CFI}=0.85)$ for the full-measurement model show adequate fit. When the uncorrelated method factor was added, we found that the model slightly improved $(\mathrm{RMSEA}=0.07, \mathrm{SRMR}=0.08, \mathrm{CFI}=0.89)$. To establish the extent of the effect of common-method bias, we calculated the variance explained by the method factor by finding the sum of the squared loadings. We observed that the total amount of variance due to the method factor was $8 \%$, which is considered far lower than the threshold of 25\% suggested by Williams, Cote and Buckley (1989). Hence, our results suggest that commonmethod bias is not a major concern in this study.

To assess the reliability and validity of our constructs, we performed confirmatory factor analysis (CFA) using LISREL 9.3 software package. Our CFA model provided adequate fit for the data: $\chi^{2}($ degree of freedom $[$ d.f.] $)=825.55(463) ; p<0.00 ;$ RMSEA $=0.04 ; \mathrm{NNFI}=0.96 ; \mathrm{CFI}=$ 
0.95 and SRMSR $=0.05$. We found that factor loadings for each construct were significant at $1 \%$, supporting convergent validity (Bagozzi and Yi, 1988).

We established reliability by inspecting Cronbach's Alpha values, composite reliability (CR) and average variance extracted (AVE) (Table 1). We found that the Cronbach's Alpha reliability, composite reliability and discriminant validity were acceptable (Bagozzi and Yi, 2012). In addition, factor loadings of each construct exceeded the suggested threshold value of 0.40 and are significant at $\mathrm{p}<0.001$. This indicates convergent validity of the constructs (e.g., Anderson and Gerbing, 1988). We also inspected the AVE of each construct and found that each construct's AVE is larger than 0.50 and higher than the squared correlation between each pair of constructs. This further supports the convergent validity of our construct (Bagozzi and Yi, 2012).

\section{Insert Table 2 about here}

\subsection{Estimation and results}

The proposed mediation model uses the procedure advanced by Baron and Kenny (1986). Before proceeding to the analyses, all the continuous variables were mean centered to account for the potential multicollinearity concerns when testing moderating effects (Aiken and West, 1991). The variance inflation factor (VIF) for each of the mean-centered variables was between 1.22 and 2.59, which is way below the suggested threshold value of 10 (Neter, et al., 1990; Baum, 2006). Hence, we concluded that multicollinearity issues do not influence our research model.

We provide details of means and standard deviations in Table 1. Bivariate correlations are

presented in Table 2. We tested our hypotheses using ordinary least square (OLS) regression analysis (Cohen et al., 2003) to establish whether the research model meets the mediation requirements suggested by Baron and Kenny (1986). According to the prescriptions of this procedure, mediation is established when the following conditions are met: (1) the independent 
variable significantly predicts both the dependent and the mediator; (2) the mediator significantly affects the dependent variable; and (3) when the mediation is added to the regression equation, the influence of the independent variable on the dependent variable is attenuated. According to the logic of this method, a full mediation is achieved if the influence of the independent variable is non-significant when the mediating variable is included in the regression equation. Partial mediation is established if the influence of the independent variable on the dependent variable is attenuated but remains significant. We present the results of the study following these steps in Table 3. We present the effect of the control variables in Model 1 and Model 2 includes the moderating variables. Model 3 presents the effect of IVs on new-venture internationalization. We found in Model 3 that IVs positively and significantly relate to new-venture internationalization $(\beta=0.29, \mathrm{p}<0.01)$. Hence, we satisfy Baron and Kenny's (1986) condition for establishing mediation. In Model 4, we test the effect of IVs on the mediating variable (ILE). The positive and significant influence of IVs on ILE $(\beta=0.26, \mathrm{p}<0.01)$ represents the second condition for achieving mediation.

Next, we examine the effect of ILE (mediator) on new-venture internationalization. Results show that ILE positively and significantly relates to new-venture internationalization $(\beta=0.27, \mathrm{p}$ $<0.01)$. We also found that, when ILE was included in the regression equation, the effect of IVs on new-venture internationalization is significantly reduced (the $\beta$ for IVs reduced from $0.29, \mathrm{p}<$ 0.01 to $0.02, n s)$. These results confirm the third condition required for mediation. Hence, our results indicate that IVs predict new-venture internationalization and that this relationship is mediated by ILE. This confirms Hypothesis 1 .

Next, we examined the moderating role of domestic-market environment (environmental dynamism and competitive intensity). The results in Model 6 show that Hypothesis $2 \mathrm{a}$ is confirmed, as the coefficient of the interaction between IVs and environmental dynamism has a 
statistically significant effect on ILE $(\beta=0.49, \mathrm{p}<0.01)$. In addition, we confirm Hypothesis $2 \mathrm{~b}$ as the empirical results in Model 7 show the interaction between IVs and domestic-market competitive intensity positively and significantly influence ILE $(\beta=0.44, \mathrm{p}<0.01)$.

In addition to the above results, we performed Sobel tests to examine the statistical significance of the indirect effect of IVs on new venture internationalization (Sobel, 1982). According to the logic of the Sobel test, the magnitude of the unstandardized indirect effect and its associated standard error must be calculated to find the Sobel statistic (ratio of unstandardized indirect effect over its standard error). To determine the statistical significance of the indirect effect, the Sobel statistic is compared to the $\mathrm{z}$ distribution. Our Sobel test shows that the indirect effect of IVs on new-venture internationalization $(\mathrm{z}=2.33, \mathrm{p}<0.01)$ was consistent with our prediction and statistically significant. This further confirms Hypothesis 1.

\section{Insert Table 3 about here}

\subsection{Robustness tests}

We undertook two additional tests to establish the robustness of our research model. First, we utilized a path analysis format (Preacher, et al., 2010) using Mplus statistical software package (Muthén and Muthén, 1998-2010) and tested our mediation model through the test of the statistical significance of the indirect effect and its associated confidence interval (MacKinnon, 2008). We found support for the mediating effect of ILE and the moderating role of environment dynamism and competitive intensity. Hypothesis 1 was supported (estimate $=0.16, \mathrm{p}<0.01 ; 95 \%$ CI $[0.10$, 0.26]). The fit heuristics for the model show adequate fit $\left(\chi^{2} / \mathrm{df}=1.45, \mathrm{RMSEA}=0.02, \mathrm{NNFI}=\right.$ 0.95, CFI $=0.98$, SRMSR $=0.06)$. Thus, these results replicate our initial findings.

Second, we used the ratio of foreign sales to total sales as a measure of degree of internationalization to estimate the alternative regression model. This approach to measure degree 
of internationalization is widely accepted (Annavarjula and Beldona, 2000). The foreign sales to total sales ratio captures the foreign market penetration of a venture (Thomas and Eden, 2004). Although the foreign sales to total sales ratio represents just one dimension of a firm's international venturing activities, it captures the importance of doing business abroad for single ventures (Oesterle, et al., 2016). Using this measure as an alternative to the subjective measures of degree of internationalization yielded the following results for the mediation hypothesis: (estimate $=0.14$, $p<0.05 ; 95 \%$; CI [0.07, 0.22]). This offers additional support for Hypothesis 1.

Third, we examined our research model by decomposing the firms into very young firms (1-5 years old) and young firms (6-10 years). Subsequently, we estimated two additional and distinct structural models. Results show the same pattern of findings when the independent variables are regressed separately on the very young and young components. Specifically, the indirect effect of IVs on degree of internationalization yielded the following results for very young firms $($ estimate $=0.17, \mathrm{p}<0.01 ; 95 \% \mathrm{CI}[0.11,0.28])$ and for young firms $($ estimate $=0.15, \mathrm{p}<$ $0.01 ; 95 \%$ CI $[0.09,0.26])$. Thus, findings remain consistent irrespective of the method used.

\section{Discussion and conclusion}

In this study, we sought to examine IVs as crucial enablers of new venture internationalization. We examined both how and when IVs enhance the degree to which new ventures are internationalized by exploring ILE as a mediator and two domestic-market environmental factors (i.e., environmental dynamism and competitive intensity). We found that a firm's ILE mediates the link between IVs and degree of internationalization. In addition, our results show that both environmental dynamism and competitive intensity moderate the indirect relationship between IVs and the degree of new-venture internationalization. 
Our findings contribute to the international business literature in several ways. First, by examining learning and knowledge accumulation in response to IVs, our study addresses an omission in the literature as one of the first empirical works to conceptualize and capture the intricate dynamics and effects of IVs on firms' operations and internationalization. Despite the importance of learning effort for emerging-market firms, there are few scholarly works on learning by such firms (see Hitt et al., 2005). We contribute to the international business literature by examining mechanisms through which IVs can be harnessed, leading to positive outcomes for firms in emerging economies.

Second, our study provides a nuanced understanding of IVs as a predictor of new-venture internationalization by exploring when it is more effective. While previous research has examined IVs and the domestic-market environment in isolation, our study offers a contingency perspective and shows that a firm's domestic-market environment offers crucial boundary conditions for the effectiveness of IVs in enabling its internationalization effort. Thus, our study adds to the international business literature by investigating the domestic-market conditions under which the indirect relationship between IVs and new-venture internationalization is effective. In doing so, we show that firms operating in an environment characterized by IVs are likely to make the effort to learn about the international business environment which can trigger international venturing activities, more so when the domestic environment is in a state of flux and highly competitive.

Third, we use unique data from Ghana, a sub-Saharan African emerging economy, to show that IVs, which are frequently prevalent in emerging markets, can serve as enablers for new venture internationalization. By taking a single country perspective, we analyze how emerging countrybased firms are likely to internationalize when IVs are present in the firm's operating environment. This is an important addition to the international business literature because very little effort has been devoted to investigating how IVs in an emerging country drive a firm's degree of 
internationalization and how market environmental conditions affect this relationship. Moreover, while previous studies show the effect of IVs on firm-level strategy and performance (Hoskisson et al., 2000; Khanna and Palepu, 1997), our study examines how and when IVs serve as enablers for firms' international venturing activities from the perspective of an emerging economy.

Overall, we advance international business literature by enhancing scholarly understanding of how and when firms can pursue international business activities. Specifically, we proposed and tested a moderated mediation model that considers how and when IVs boost a firm's degree of internationalization. Hence, we show the importance of concurrently examining mediating and moderating influences to advance scholarly effort in understanding how IVs may trigger the degree to which firms embark on international venturing activities.

Our study has implications for practice too. First, the results indicate that, for emergingmarket new ventures, IVs through ILE can help them to do business outside the borders of their home country. While previous studies indicate that the presence of IVs create institutional vacuums for firms (Khanna and Palepu, 1997, 2000a, 2000b), we show that this vacuum helps new ventures to expand their activities beyond the home country. This insight is particularly relevant for emerging-market new ventures that operate in institutionally challenged environments, which are mostly characterized by low levels of institutional development due to the absence of institutional rules, or the presence of ambiguous or poorly enforced rules.

Second, by demonstrating IVs as a trigger for learning efforts among new ventures, there is a need for aspiring and existing entrepreneurs to shift their mindsets from viewing local institutions as "barriers" to viewing them as "opportunities" to increase or engage in innovation activities and learn. By being able to navigate around the voids, the new ventures would be better equipped to expand into neighboring African countries and other emerging economies, which tend to have similar institutional constraints. Thus, the learning capabilities become difficult for rival 
firms to mimic. From a public policy standpoint, there is a need for the national government to promote exporting and international expansion not only as a national necessity but also as a means for local firms to spread their risks and improve their survival chances. Results from our study show that IVs promote internationalization of new ventures through learning. An implication is that emerging-economy governments could develop and promote educational programs to help entrepreneurs learn. This can be done by promoting knowledge exchange among new firms and aspiring entrepreneurs. In addition, entrepreneurs can learn from networking derived from social and business ties. Such learning can equip local firms for new markets.

\section{Limitations and direction for future research}

Despite the study's contributions to practice, it has some limitations with the potential of opening future research avenues. First, our study finds a significant mediating effect of ILE on the relationship between IVs and new-venture internationalization. However, arguments can be made that certain firm- or individual-level dispositions can complement the mediating effect of learning on the link between IVs and new-venture internationalization. For example, Boso et al. (2018) found that the effect of learning on new venture performance is dependent on entrepreneurial alertness to market opportunities. Thus, the international business literature will be advanced if future studies extend the current model by investigating boundary conditions that are relevant to the international learning-new-venture internationalization relationship.

Second, the study collected data at one point in time. In this case, there is a limitation of the extent to which causal inferences can be made (Rindfleisch et al., 2008). Although our newventure internationalization data were lagged relative to the independent variables, this does not entirely take away the issues of causality. In addition, we used the ratio of foreign sales to total sales as a measure of degree of internationalization to estimate an alternative regression model in our robustness test. We suggest that the literature will benefit from a more nuanced finding if future 
research adopts a longitudinal approach in data collection for similar studies. Third, we used firms that are operating in a developing economy within the African continent. This limits the generalization of our findings to such a specific context. Future studies across other developing and developed countries will further deepen the discourse and, most importantly, contribute to the strategy and international business literature. Finally, the geographical location of a firm has the potential to influence that firm's degree of internationalization (Fernhaber, et al., 2008). A major reason is that some ventures located in urban centers can acquire the resources required to embark on internationalization. Future studies should control for firm location (urban and rural).

\section{References}

Acquaah, M. 2007. Managerial social capital, strategic orientation, and organizational performance in an emerging economy. Strategic Management Journal, 28: 1235-1255.

Adomako, S., Opoku, R. A., \& Frimpong, K. 2017. The Moderating Influence of Competitive Intensity on the Relationship between CEOs' Regulatory Foci and SME Internationalization. Journal of International Management, 23(3): 268-278.

Aiken, L.S, and West, S.G. 1991. Multiple Regression: Testing and Interpreting Interactions. SAGE Publications: Thousand Oaks, CA.

Amankwah-Amoah, J. 2016. An integrative process model of organisational failure. Journal of Business Research, 69(9): 3388-3397.

Amankwah-Amoah, J., \& Debrah, Y. A. 2010. The protracted collapse of Ghana Airways: Lessons in organizational failure. Group \& Organization Management, 35(5): 636-665.

Amankwah-Amoah, J., Debrah, Y., \& Nuertey, D. 2018. Institutional legitimacy, cross-border trade and institutional voids: Insights from the cocoa industry in Ghana. Journal of Rural Studies, 58: 136-145.

Anderson, J. C., \& Gerbing, D. W. 1988. Structural equation modeling in practice: A review and recommended two-step approach. Psychological Bulletin, 103(3): 411-423

Ang, S. H. 2008. Competitive intensity and collaboration: impact on firm growth across technological environments. Strategic Management Journal, 29 (10): 1057-1075.

Annavarjula, M., \& Beldona, S. 2000. Multinationality-performance relationship: A review and reconceptualization. International Journal of Organizational Analysis, 8(1): 48-67.

Auh, S., \& Menguc, B. 2005. Balancing exploration and exploitation: the moderating role of competitive intensity. Journal of Business Research, 58(12): 1652-1661.

Autio, E., Sapienza, H. J., \& Almeida, J. G. 2000. Effects of age at entry, knowledge intensity, and imitability on international growth. Academy of Management Journal, 43(5): 909-924.

Ayyagari, M., Dau, L. A., \& Spencer, J. (2015). Strategic responses to FDI in emerging markets: Are core members more responsive than peripheral members of business groups?. Academy of Management Journal, 58(6), 1869-1894. 
Bagozzi, R. P., \& Yi, Y. 1988. On the evaluation of structural equation models. Journal of the Academy of Marketing Science, 16(1): 74-94.

Bagozzi, R. P., \& Yi, Y. 2012. Specification, evaluation, and interpretation of structural equation models. Journal of the Academy of Marketing Science, 40(1): 8-34.

Baron, R.M, and Kenny, D.A. 1986. The moderator-mediator variable distinction in social psychological research: conceptual, strategic, and statistical considerations. Journal of Personality and Social Psychology, 51(6): 1173-1182.

Baum, C. F. 2006. Introduction to modern econometrics using Stata. Texas: Sata Press.

Boso, N., Story, V. M., Cadogan, J. W., Micevski, M., \& Kadić-Maglajlić, S. 2013. Firm innovativeness and export performance: Environmental, networking, and structural contingencies. Journal of Marketing Research, 21(4): 62-87.

Bruton, G. D., Ketchen Jr, D. J., \& Ireland, R. D. 2013. Entrepreneurship as a solution to poverty. Journal of Business Venturing, 28(6), 683-689.

Brouthers, K. D., \& Brouthers, L. E. 2003. Why service and manufacturing entry mode choices differ: The influence of transaction cost factors, risk and trust. Journal of Management Studies, 40(5), 1179-1204.

Bruderl, J., \& Schussler, R. 1990. Organizational mortality: The liabilities of newness and adolescence. Administrative Science Quarterly, 530-547.

Cadogan, J.W., Cui, C.C., \& Yeung, E.K. (2003). Export market-oriented behaviour and export performance, the moderating roles of competitive intensity and technological turbulence. International Marketing Review, 20(5), 493-513

Cardon, M. S., \& Kirk, C. P. 2015. Entrepreneurial passion as mediator of the self-efficacy to persistence relationship. Entrepreneurship Theory and Practice, 39(5): 1027-1050.

Cavusgil, S.T, Knight, G., \& Riesenberger, J. 2012. International business: strategy, management, and the new realities. Upper Saddle River, NJ: Prentice Hall.

Cohen, W. M., \& Levinthal, D. A. 1990. Absorptive capacity: A new perspective on learning and innovation. Administrative Science Quarterly, 35: 128-152.

Osei, C., Amankwah-Amoah, J., Khan, Z., Omar, M., \& Gutu, M. (2018). Developing and deploying marketing agility in an emerging economy: the case of Blue Skies. International Marketing Review.

Dacin, M. T., Dacin, P. A., \& Tracey, P. 2011. Social entrepreneurship: a critique and future directions. Organization Science, 22(5): 1203-1213.

Dai, L., V. Maksimov, Gilbert, B. A. \& Fernhaber. S. A. (2014). Entrepreneurial Orientation and International Scope: The Differential Roles of Innovativeness, Proactiveness, and Risk-taking. Journal of Business Venturing 29 (4): 511-524.

Dau, L. A. (2013). Learning across geographic space: Pro-market reforms, multinationalization strategy, and profitability. Journal of International Business Studies, 44(3), 235-262.

De Clercq, D., Sapienza, H. J., \& Zhou, L. 2014. Entrepreneurial strategic posture and learning effort in international ventures: The moderating roles of operational flexibilities. International Business Review, 23(5): 981-992.

De Clercq, D., Sapienza, H. J., Yavuz, R. I., \& Zhou, L. 2012. Learning and knowledge in early internationalization research: Past accomplishments and future directions. Journal of Business Venturing, 27(1): 143-165.

De Lange, D.E., 2016. Legitimation strategies for clean technology entrepreneurs facing institutional voids in emerging economies. Journal of International Management, 22(4), 403-415.

Dicken, P. 2007. Global shift: Mapping the changing contours of the world economy. SAGE 
Publications Ltd.

Easterby-Smith, M., \& Lyles, M. A. Eds. 2011. Handbook of organizational learning and knowledge management. John Wiley \& Sons.

Easterby-Smith, M., Crossan, M., \& Nicolini, D. (2000). Organizational learning: debates past, present and future. Journal of management studies, 37(6), 783-796.

Eisenhardt, K. M., \& Bourgeois, L. J. III. 1988. Politics of strategic decision making in highvelocity environments: Toward a midrange theory. Academy of Management Journal, 31: 737-770.

Erramilli, M. K., \& Rao, C. P. 1993. Service firms' international entry-mode choice: A modified transaction-cost analysis approach. The Journal of Marketing19-38

Eriksson, K., Johanson, J., Majkgard, A., \& Sharma, D. D. 1997. Experiential knowledge and cost in the internationalization process. Journal of International Business Studies, 28: 337-360.

Felin, T., \& Hesterly, W. S. 2007. The knowledge-based view, nested heterogeneity, and new value creation: Philosophical considerations on the locus of knowledge. Academy of Management Review, 32(1): 195-218.

Fernhaber, S. A., Gilbert, B. A., \& McDougall, P. P. 2008. International entrepreneurship and geographic location: an empirical examination of new venture internationalization. Journal of International Business Studies, 39, 267-290.

Fiol, C. M., \& Lyles, M. A. 1985. Organizational learning. Academy of management review, 10(4): 803-813.

Gao, Y., Gao, S., Zhou, Y., \& Huang, K. F. 2015. Picturing firms' institutional capital-based radical innovation under China's institutional voids. Journal of Business Research, 68(6), 11661175.

Garrone, P., Piscitello, L. and D'Amelio, M., 2018. Multinational Enterprises and the Provision of Collective Goods in Developing Countries under Formal and Informal Institutional Voids. The Case of Electricity in Sub-Saharan Africa. Journal of International Management.

Giachetti, C. 2016. Competing in emerging markets: Performance implications of competitive aggressiveness. Management International Review, 56(3): 325-352.

Grant, R. M. 1996. Toward a knowledge-based theory of the firm. Strategic Management Journal, 17(S2): 109-122.

Greenwood, P. E., \& Nikulin, M. S. 1996. A Guide to Chi-Squared Testing. New York: Wiley.

Heyden, M. L., Van Doorn, S., Reimer, M., Van Den Bosch, F. A., \& Volberda, H. W. 2013. Perceived environmental dynamism, relative competitive performance, and top management team heterogeneity: Examining correlates of upper echelons' adviceseeking. Organization Studies, 34(9): 1327-1356.

Hill, C. W.L., \& Hult, G. T. M. 2018. Global Business Today, 10th Edition, McGraw-Hill.

Hitt, M. A., Li, H., \& Worthington, W. J. 2005. Emerging markets as learning laboratories: Learning behaviors of local firms and foreign entrants in different institutional contexts. Management and Organization Review, 1: 353-380.

Hoskisson, R. E., Eden, L., Lau, C. M., \& Wright, M. 2000. Strategy in emerging economies. Academy of Management Journal, 43: 249-267.

Huber, G. P. 1991. Organizational learning: an examination of the contributing processes and the literatures. Organization Science, 2: 88-115.

Hyysalo, S. (2009). Learning for learning economy and social learning. Research Policy, 38(5), 726-735.

Ibeh, K., Wilson, J., \& Chizema, A. (2012). The internationalization of African firms 1995-2011: Review and implications. Thunderbird International Business Review, 54(4), 411-427. 
Jansen, J.J.P., Van Den Bosch, F.A.J., \& Volberda, H.W. 2006. Exploratory innovation, exploitative innovation, and performance: effects of organizational antecedents and environmental moderators. Management Science, 52 (11): 1661-1674.

Jones, G. 2012. The growth opportunity that lies next door. Harvard Business Review, 90(7-8): 141-145.

Julian, S. D., \& Ofori-Dankwa, J. C. 2013. Financial resource availability and corporate social responsibility expenditures in a sub-Saharan economy: The institutional difference hypothesis. Strategic Management Journal, 34(11): 1314-1330.

Kalvet, T., Barnard, H., \& Tiits, M. 2013. Institutional voids as a trigger for the emergence of born global production and innovation networks. 35th DRUID Celebration Conference, Barcelona.

Khanna T., \& Palepu K. 2010. Winning in emerging markets: A road map for strategy and execution. Harvard Business School Press: Boston, MA

Khanna, T., \& Palepu, K. 1997. Why focused strategies may be wrong for emerging markets. Harvard Business Review, 75(4): 41-51.

Khanna, T., \& Palepu, K. 1999. Policy shocks, market intermediaries, and corporate strategy: The evolution of business groups in Chile and India. Journal of Economics and Management Strategy, 8: 271-310.

Khanna, T., \& Palepu, K. 2000a. The future of business groups in emerging markets: Long-run evidence from Chile. Academy of Management Journal, 43(3): 268-285.

Khanna, T., \& Palepu, K. 2000b. Is group affiliation profitable in emerging markets? An analysis of diversified Indian business groups. Journal of Finance, 55(2): 867-981.

Kogut, B., \& Zander, U. 1992. Knowledge of the firm, combinative capabilities, and the replication of technology. Organization Science, 3, 383-397.

Lall, S. 1983. The new multinationals: The spread of Third World enterprises, New York: Wiley.

Laufs, K., Bembom, M., \& Schwens, C. 2016. CEO characteristics and SME foreign market entry mode choice: The moderating effect of firm's geographic experience and host-country political risk. International Marketing Review, 33(2): 246-275.

Lee, J. J., \& Yoon, H. (2015). A comparative study of technological learning and organizational capability development in complex products systems: Distinctive paths of three latecomers in military aircraft industry. Research Policy, 44(7), 1296-1313.

Leechor, C. 1994. Ghana: Forerunner in adjustment. In Hussain, I., \& Faruque, R., (eds). Adjustment in Africa. The World Bank: Washington, DC: 153-192.

Levitt, B., \& March, J. G. 1988. Organizational learning. Annual Review of Sociology, 14, 319340

Lindell, M. K., \& Whitney, D. J. 2001. Accounting for common method variance in crosssectional research designs. Journal of Applied Psychology, 86(1): 114-121.

Madsen, T. K., \& Servais, P. 1997. The internationalization of born globals: an evolutionary process?. International Business Review, 6(6), 561-583.

Mair, J., \& Marti, I. 2009. Entrepreneurship in and around institutional voids: A case study from Bangladesh. Journal of Business Venturing, 24(5): 419-435.

Mair, J., Marti, I., \& Ventresca, M. J. 2012. Building inclusive markets in rural Bangladesh: How intermediaries work institutional voids. Academy of Management Journal, 55(4): 819-850.

Martin, S. L., \& Javalgi, R. R. G. 2016. Entrepreneurial orientation, marketing capabilities and performance: the moderating role of competitive intensity on Latin American International new ventures. Journal of Business Research, 69(6), 2040-2051. 
Meyer, K. E., Estrin, S., Bhaumik, S. K., \& Peng, M. W. 2009. Institutions, resources, and entry strategies in emerging economies. Strategic Management Journal, 30(1): 61-80.

Miller, D., \& P. H. Friesen. 1982. Innovation in conservative and entrepreneurial firms: Two models of strategic momentum. Strategic Management Journal, 3(1): 1-25.

Millward, R. 2005. Private and public enterprise in Europe: energy, telecommunications and transport, 1830-1990. Cambridge University Press.

Morgan, N. A., Kaleka, A., \& Katsikeas, C. S. 2004. Antecedents of export venture performance: A theoretical model and empirical assessment. Journal of Marketing, 68(1), 90-108.

Musteen, M., Francis, J., \& Datta, D. K. 2010. The influence of international networks on internationalization speed and performance: a study of Czech SMEs. Journal of World Business, 45(3): 197-205.

Muthén L. K., Muthén B. O. 1998-2010. Mplus user's guide (6th ed.). Los Angeles, CA: Muthén \& Muthén.

Neter, J., Wasserman, W., \& Kutner, M. H. 1990. Regression, analysis of variance, and experimental design. Applied Statistical Models, 614-619.

North, D. 1990. Institutions, Institutional Change, and Economic Performance. Cambridge University Press: New York,

Oesterle, M. J., Elosge, C., \& Elosge, L. 2016. Me, myself and I: The role of CEO narcissism in internationalization decisions. International Business Review, 25(5): 1114-1123.

Oesterle, M.J., \& Richta, H. N. 2013. Internationalization and firm performance: state of empirical research efforts and need for improved approaches. European Journal of International Management, 7/2: 204-224.

Ofori-Dankwa, J., \& Julian, S. D. 2013. Dynamism, capital structure, and performance in a subSaharan economy: Extending the institutional difference hypothesis. Organization Science, 24(5): 1422-1438.

Peng, M. W. 2014. Global Business. 3rd edition. Cincinnati: Cengage Learning.

Peng, M. W., Wang, D. Y., \& Jiang, Y. 2008. An institution-based view of international business strategy: A focus on emerging economies. Journal of international business studies, 39(5): 920-936.

Porter, M. E. 1991. Towards a dynamic theory of strategy. Strategic Management Journal, 12, 95-117.

Preacher K. J., Zyphur M. J., \& Zhang Z. 2010. A general multilevel SEM framework for assessing multilevel mediation. Psychological Methods, 15: 209-233.

Preacher, K. J., Rucker, D. D., \& Hayes, A. F. 2007. Addressing moderated mediation hypotheses: Theory, methods, and prescriptions. Multivariate Behavioral Research, 42(1): 185-227.

Ramamurti, R., \& Singh, J. V. 2009. Emerging multinationals in emerging markets. Cambridge: Cambridge University Press.

Reynolds, P., \& Miller, B. 1992. New firm gestation: Conception, birth, and implications for research. Journal of Business Venturing, 7(5): 405-417.

Ripollés, M., Blesa, A., \& Monferrer, D. 2012. Factors enhancing the choice of higher resource commitment entry modes in international new ventures. International Business Review, 21(4): 648-666.

Rogelberg, S., \& Stanton, J. 2007. Understanding and dealing with organizational survey nonresponse. Organizational Research Methods, 10(2): 195-209.

Sapienza, H. J., De Clercq, D., \& Sandberg, W. R. 2005. Antecedents of international and domestic learning effort. Journal of Business Venturing, 20(4): 437-457.

Schwens, C., \& Kabst, R. 2009. How early opposed to late internationalizers learn: experience of 
others and paradigms of interpretation. International Business Review, 18, 509-522.

Scott, W. R. 1995. Institutions and organizations. Thousand Oaks, CA: Sage.

Sobel, M. E. 1982. Asymptotic confidence intervals for indirect effects in structural equation models. Sociological Methodology, 13, 290-312.

Stewart Jr, W. H., May, R. C., \& Kalia, A. 2008. Environmental perceptions and scanning in the United States and India: convergence in entrepreneurial information seeking?. Entrepreneurship Theory and Practice, 32(1), 83-106.

Stinchcombe, A. L. 1965. Social structures and organizations. In James G. March (ed.), Handbook of Organizations: 142-193. Chicago: Rand McNally.

Vandenberg, R. J., \& Lance, C. E. 2000. A review and synthesis of the measurement invariance literature: Suggestions, practices, and recommendations for organizational research. Organizational Research Methods, 3(1): 4-70.

Wang, C. L. 2008. Entrepreneurial orientation, learning orientation, and firm performance. Entrepreneurship Theory and Practice, 32(4): 635-657.

Wiklund, J., \& Shepherd, D. 2005. Entrepreneurial orientation and small business performance: a configurational approach. Journal of Business Venturing, 20(1): 71-91.

Wiklund, J., \& Shepherd, D. A. 2011. Where to from here? EO-as-experimentation, failure, and distribution of outcomes. Entrepreneurship Theory and Practice, 35(5), 925-946.

Williams, L. J., Cote, J. A., \& Buckley, M. R. 1989. Lack of method variance in self-reported affect and perceptions at work: reality or artifact?. Journal of Applied Psychology, 74(3): 462-468

Wright, M., Filatotchev, I., Hoskisson, R. E., \& Peng, M. W. 2005. Strategy research in emerging economies: Challenging the conventional wisdom. Journal of management studies, 42(1), $1-33$.

Zacharakis, A. L. 1997. Entrepreneurial entry into foreign markets: a transaction cost perspective, Entrepreneurship Theory and Practice, 21(3): 23-39.

Zaheer, S., \& Mosakowski, E. 1997. The dynamics of the liability of foreignness: A global study of survival in financial services. Strategic Management Journal, 18(6): 439-464.

Zahra, S. A., \& Das, S. R. 1993. Innovation strategy and financial performance in manufacturing companies: An empirical study. Production and operations management, 2(1), 15-37.

Zahra, S. A., Gedajlovic, E., Neubaum, D. O., \& Shulman, J. M. 2009. A typology of social entrepreneurs: motives, search processes and ethical challenges. Journal of Business Venturing, 24(5): 519-532.

Zahra, S. A., Ireland, R. D., \& Hitt, M. A. 2000. International expansion by new venture firms: International diversity, mode of entry, technological learning, and performance. Academy of Management Journal, 43(5): 925-950.

Zahra, S.A., Neubaum, D.O., \& Huse, M. 2000. Entrepreneurship in medium-size companies: exploring the effects of ownership and governance systems. Journal of Management, 26 (5): 947-976. 


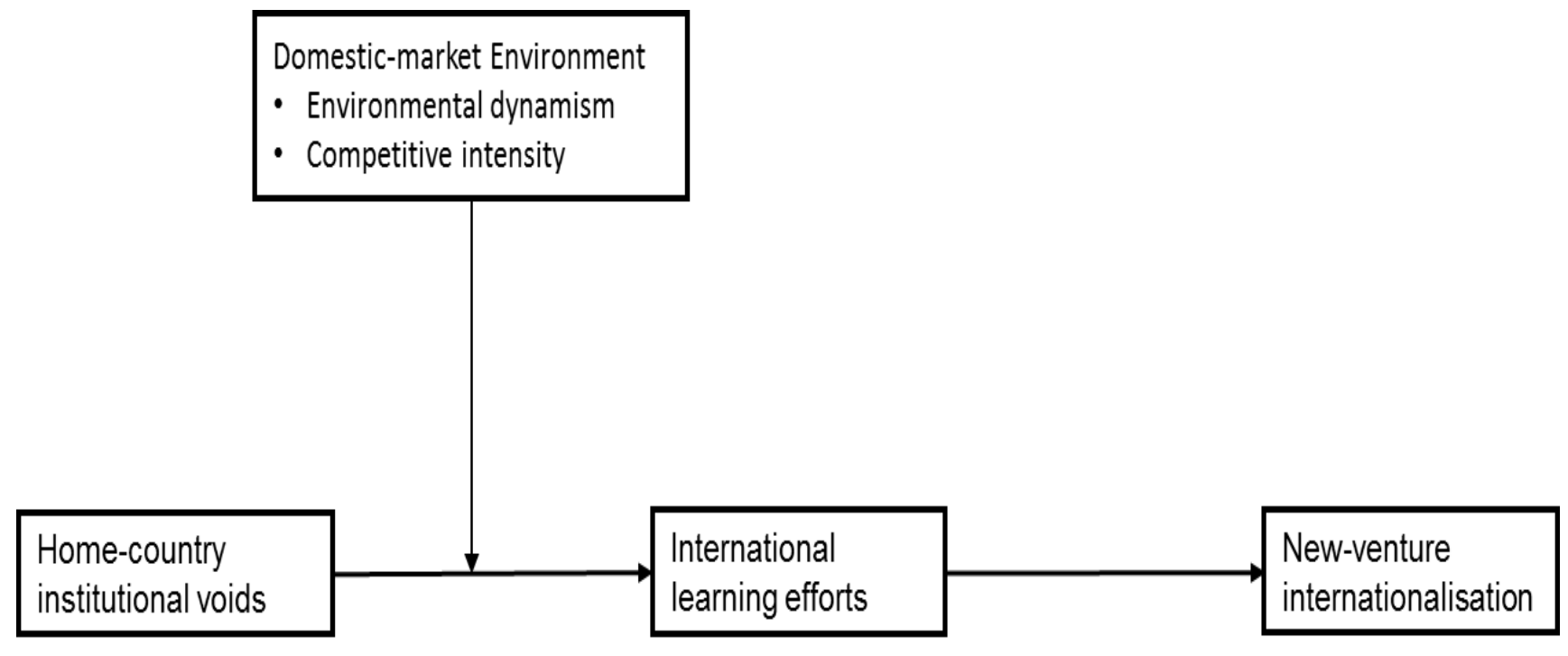

Figure 1: Conceptual model of the study 
Table 1: Descriptive statistics, validity and reliability tests

\begin{tabular}{|c|c|c|c|c|c|c|}
\hline Model variable & Item descriptions & Mean (SD) & 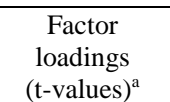 & $\begin{array}{c}\text { Cronbach's } \\
\alpha\end{array}$ & $\mathrm{CR}$ & AVE \\
\hline \multicolumn{7}{|c|}{$\begin{array}{l}\text { To what extent do you agree with the following statements describing your business environment? Please circle the number that best represents your } \\
\text { opinion. } 1=\text { not at all } ; 7=\text { to an extreme extent. }\end{array}$} \\
\hline \multirow[t]{4}{*}{$\begin{array}{l}\text { Institutional voids } \\
\text { (Giachetti, 2016) }\end{array}$} & $\begin{array}{l}\text { Lack of infrastructure to facilitate the relationship } \\
\text { between the firm and its clients, or between the firm } \\
\text { and its suppliers }\end{array}$ & $4.62(1.60)$ & $0.89(1.00)$ & 0.84 & 0.86 & 0.59 \\
\hline & $\begin{array}{l}\text { We were able to find adequate and reliable information } \\
\text { about the tastes and preferences of consumers, and the } \\
\text { reliability of suppliers with ease ( } r \text { ) }\end{array}$ & $4.75(1.55)$ & $0.88(28.11)$ & & & \\
\hline & $\begin{array}{l}\text { Underdeveloped education infrastructures and the need } \\
\text { for intensive training of Ghanaian employees }\end{array}$ & $4.12(1.63)$ & $0.86(26.70)$ & & & \\
\hline & Ambiguous bureaucratic and legal system & & & & & \\
\hline \multirow{4}{*}{$\begin{array}{l}\text { Financial resource } \\
\text { (Wiklund and } \\
\text { Shepherd, 2005). }\end{array}$} & $\begin{array}{l}\text { - Our company has difficulty in accessing financial } \\
\text { capital to support its business operations (r) }\end{array}$ & $4.51(1.15)$ & $0.80(1.00)$ & 0.94 & 0.96 & 0.65 \\
\hline & $\begin{array}{l}\text { - If we need more financial assistance for our business } \\
\text { operations, we could easily get it }\end{array}$ & $4.80(1.16)$ & $0.77(18.47)$ & & & \\
\hline & $\begin{array}{l}\text { - We have substantial financial resources at the } \\
\text { discretion of managers for funding business initiatives }\end{array}$ & $4.75(1.55)$ & $0.83(17.30)$ & & & \\
\hline & $\begin{array}{l}\text { - We are able to obtain financial resources at short } \\
\text { notice to support business operations }\end{array}$ & $4.82(1.22)$ & $0.82(17.28)$ & & & \\
\hline \multicolumn{7}{|c|}{$\begin{array}{l}\text { To what extent do you agree with the following statements describing your business environment? Please circle the number that best represents your } \\
\text { opinion. } 1=\text { not at all; } 7=\text { to an extreme extent. }\end{array}$} \\
\hline \multirow[t]{3}{*}{$\begin{array}{l}\text { Environment } \\
\text { dynamism }\end{array}$} & $\begin{array}{l}\text { Competitors are constantly trying out new competitive } \\
\text { strategies }\end{array}$ & $4.74(1.11)$ & $0.92(1.00)$ & 0.90 & .091 & .64 \\
\hline & $\begin{array}{l}\text { Customer needs and demands are changing rapidly in } \\
\text { our industry }\end{array}$ & $3.82(1.60)$ & $0.84(15.48)$ & & & \\
\hline & $\begin{array}{l}\text { New markets are emerging for products and services in } \\
\text { our industry }\end{array}$ & $4.81(1.20)$ & $0.87(26.30)$ & & & \\
\hline \multirow{4}{*}{$\begin{array}{l}\text { Competitive intensity } \\
\text { (Jansen et al., 2006). }\end{array}$} & Competition in our local market is intense & $4.69(1.05)$ & $0.88(1.00)$ & 0.89 & 0.90 & 0.68 \\
\hline & $\begin{array}{l}\text { Our organizational unit has relatively strong } \\
\text { competitors }\end{array}$ & $5.75(0.88)$ & $0.86(15.97)$ & & & \\
\hline & Competition in our local market is extremely high & $5.58(0.89)$ & $0.83(15.46)$ & & & \\
\hline & Price competition is a hallmark of our local market & & $0.72(14.89)$ & & & \\
\hline \multicolumn{7}{|c|}{$\begin{array}{l}\text { To what extent do you agree with following statements relating to activities to develop new knowledge in foreign markets. } 1=\text { not at all; } 7=\text { to an } \\
\text { extreme extent }\end{array}$} \\
\hline \multirow{7}{*}{$\begin{array}{l}\text { International learning } \\
\text { effort (De Clercq, } \\
\text { Sapienza and Zhou, } \\
\text { 2014) }\end{array}$} & $\begin{array}{l}\text { We put great effort into developing new knowledge } \\
\text { regarding competitors who operate in foreign markets }\end{array}$ & $5.55(1.11)$ & $0.85(1.00)$ & 0.88 & 0.90 & 0.56 \\
\hline & $\begin{array}{l}\text { We put great effort into developing new knowledge } \\
\text { regarding foreign cooperative agreements in our } \\
\text { industry }\end{array}$ & $5.04(1.43)$ & $0.77(16.46)$ & & & \\
\hline & $\begin{array}{l}\text { We put great effort into developing new knowledge } \\
\text { regarding foreign laws that affect our business }\end{array}$ & $5.45(1.32)$ & $0.87(18.77)$ & & & \\
\hline & $\begin{array}{l}\text { We put great effort into developing new knowledge } \\
\text { regarding foreign business norms affecting our industry }\end{array}$ & $3.63(1.78)$ & $0.64(14.73)$ & & & \\
\hline & $\begin{array}{l}\text { We put great effort into developing new internal } \\
\text { procedures for our foreign activities }\end{array}$ & $4.50(1.16)$ & $0.93(29.88)$ & & & \\
\hline & $\begin{array}{l}\text { We put great effort into developing new reward } \\
\text { systems for our foreign activities }\end{array}$ & $5.02(1.41)$ & $0.90(28.24)$ & & & \\
\hline & $\begin{array}{l}\text { We put great effort into developing new knowledge in } \\
\text { foreign markets. }\end{array}$ & $4.83(1.12)$ & $0.87(26.27)$ & & & \\
\hline \multicolumn{7}{|c|}{$\begin{array}{l}\text { To what extent do you agree with the following items describing your firm's activities? Please circle the number that best represents your opinion } 1= \\
\text { strongly disagree; } 7 \text { =strongly agree, }\end{array}$} \\
\hline \multirow{4}{*}{$\begin{array}{l}\text { New venture } \\
\text { internationalization } \\
\text { (Zahra et al., 2000) }\end{array}$} & Entering new foreign markets & $4.69(1.57)$ & $0.84(16.44)$ & 0.91 & 0.93 & 0.62 \\
\hline & Expanding the firm's international operations & $4.50(1.16)$ & $0.82(16.04)$ & & & \\
\hline & $\begin{array}{l}\text { Supporting start-up business activities dedicated to } \\
\text { international operations }\end{array}$ & $4.68(1.04)$ & $0.94(29.75)$ & & & \\
\hline & $\begin{array}{l}\text { Financing start-up business activities dedicated to } \\
\text { international operations }\end{array}$ & $3.82(1.61)$ & $0.75(15.52)$ & & & \\
\hline \multicolumn{7}{|c|}{ Please answer the following questions by writing down your responses } \\
\hline \multirow[t]{2}{*}{ Observed variables } & - Firm age $(\log )$ & $8.56(6.63)$ & & & & \\
\hline & - Firm size $(\log )$ & $8.13(12.47)$ & & & & \\
\hline
\end{tabular}




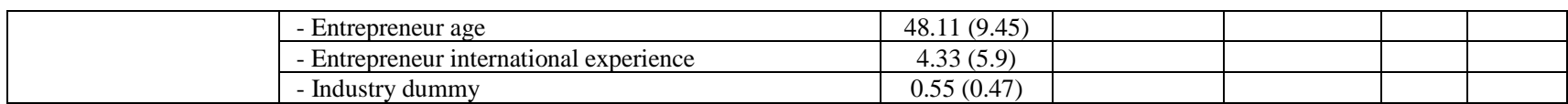

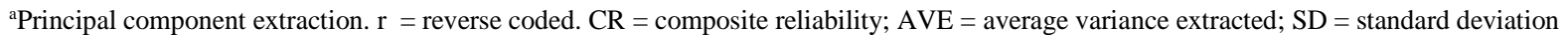

Table 2. Bivariate correlations

\begin{tabular}{|c|c|c|c|c|c|c|c|c|c|c|c|c|}
\hline & Variables & 1 & 2 & 3 & 4 & 5 & 6 & 7 & 8 & 9 & 10 & 11 \\
\hline 1. & Firm size & & & & & & & & & & & \\
\hline 2. & Firm age & -0.02 & & & & & & & & & & \\
\hline 3. & Entrepreneur's age & -0.03 & -0.04 & & & & & & & & & \\
\hline 4. & $\begin{array}{l}\text { Entrepreneur's } \\
\text { international } \\
\text { experience }\end{array}$ & -0.01 & 0.03 & $.26^{* *}$ & & & & & & & & \\
\hline 5. & Industry type & -0.04 & -0.02 & 0.01 & .03 & & & & & & & \\
\hline 6. & $\begin{array}{l}\text { Financial resource } \\
\text { availability }\end{array}$ & $0.15 * *$ & $0.25 * *$ & 0.02 & .02 & 0.04 & (0.80) & & & & & \\
\hline 7. & $\begin{array}{l}\text { Environmental } \\
\text { dynamism }\end{array}$ & -0.02 & -0.04 & 0.00 & .01 & 0.04 & 0.00 & $(\mathbf{0 . 8 0})$ & & & & \\
\hline 8. & Competitive intensity & -0.04 & -0.03 & 0.00 & .03 & 0.05 & 0.01 & 0.02 & $(\mathbf{0 . 8 2})$ & & & \\
\hline 9. & $\begin{array}{l}\text { International learning } \\
\text { effort }\end{array}$ & -0.03 & -0.05 & 0.07 & $.28 * *$ & 0.06 & $\begin{array}{l}0.23 * \\
*\end{array}$ & $0.23 * *$ & $0.13^{*}$ & (0.76) & & \\
\hline 10. & Institutional voids & $-0.09 *$ & -0.03 & 0.00 & $.08 *$ & $0.18 * *$ & 0.02 & 0.05 & $0.13^{*}$ & $0.28 * *$ & $(0.76)$ & \\
\hline 11. & $\begin{array}{l}\text { New venture } \\
\text { internationalization }\end{array}$ & -0.04 & -0.05 & 0.06 & $.35^{* * *}$ & 0.03 & $0.14 *$ & $0.13^{*}$ & $0.10^{*}$ & $0.29 * *$ & $0.22 * *$ & $\begin{array}{l}(0.78) \\
\end{array}$ \\
\hline
\end{tabular}

$\mathrm{N}=211 ; *_{\mathrm{p}}<0.05 ; * * \mathrm{p}<0.01$ (2-tailed test); S.D. = Standard deviation. Square roots of AVE in diagonal 
Table 3. Results of direct, indirect and moderating effects ${ }^{\mathrm{a}}$

\begin{tabular}{|c|c|c|c|c|c|c|c|}
\hline Variables & $\begin{array}{c}\text { Model } 1 \\
\text { New venture } \\
\text { internationalizat } \\
\text { ion }\end{array}$ & $\begin{array}{l}\text { Model } 2 \\
\text { New venture } \\
\text { internationalizat } \\
\text { ion }\end{array}$ & $\begin{array}{l}\text { Model } 3 \\
\text { New venture } \\
\text { internationalizat } \\
\text { ion }\end{array}$ & $\begin{array}{l}\text { Model } 4 \\
\text { International } \\
\text { learning } \\
\text { effort }\end{array}$ & $\begin{array}{l}\text { Model } 5 \\
\text { New venture } \\
\text { internationalizat } \\
\text { ion }\end{array}$ & $\begin{array}{l}\text { Model } 6 \\
\text { International } \\
\text { learning } \\
\text { effort }\end{array}$ & $\begin{array}{l}\text { Model } 7 \\
\text { International } \\
\text { learning } \\
\text { effort }\end{array}$ \\
\hline Firm size $^{\mathrm{b}}$ & -0.02 & -0.03 & -0.03 & -0.04 & -0.03 & -0.04 & -0.05 \\
\hline Firm age ${ }^{\mathrm{b}}$ & -0.04 & -0.03 & -0.04 & -0.06 & -0.04 & -0.05 & -0.04 \\
\hline Entrepreneur's age & $0.09 *$ & $0.09 *$ & $0.10^{*}$ & $0.07 *$ & $0.07 *$ & $0.08^{*}$ & $0.09 *$ \\
\hline Industry dummy & 0.04 & 0.05 & 0.05 & 0.06 & 0.04 & $0.07 *$ & $0.08 *$ \\
\hline $\begin{array}{l}\text { Financial resources } \\
\text { availability }\end{array}$ & $0.14 * *$ & $0.14 * *$ & $0.13 * *$ & $0.15^{* * *}$ & $0.14^{* *}$ & $0.14 * *$ & $0.14 * *$ \\
\hline $\begin{array}{l}\text { Environmental } \\
\text { dynamism (CD) }\end{array}$ & & $0.13 * *$ & $0.15 * * *$ & $0.19 * * *$ & $0.16^{* * *}$ & $0.17 * * *$ & $0.18 * * *$ \\
\hline $\begin{array}{l}\text { Competitive intensity } \\
\text { (CI) }\end{array}$ & & $0.12 *$ & $0.13 * *$ & $0.14 * *$ & $0.13 * *$ & $0.14 * *$ & $0.14 * *$ \\
\hline Institutional voids (IV) & & & $0.29 * * *$ & $0.26 * * *$ & 0.02 & $0.27 * * *$ & $0.29 * * *$ \\
\hline \multicolumn{8}{|l|}{ Mediating effect } \\
\hline $\begin{array}{l}\text { International learning } \\
\text { effort }\end{array}$ & & & & & $0.27 * * *$ & & \\
\hline \multicolumn{8}{|l|}{ Moderating effects } \\
\hline IV x CD & & & & & & $0.49 * * *$ & \\
\hline IV x CI & & & & & & & $0.44 * * *$ \\
\hline F-value & $2.28 *$ & $3.49 * *$ & $5.29 * * *$ & $5.52 * * *$ & $5.99 * * *$ & $6.86 * * *$ & $6.97 * * *$ \\
\hline $\mathrm{R}^{2}$ & 0.14 & 0.21 & 0.28 & 0.34 & 0.37 & 0.42 & 0.49 \\
\hline$\Delta \mathrm{R}^{2}$ & - & 0.07 & 0.07 & 0.06 & 0.03 & 0.05 & 0.07 \\
\hline Mean VIF & 2.03 & 1.22 & 1.66 & 2.59 & 1.77 & 2.33 & 1.88 \\
\hline
\end{tabular}

${ }^{\text {a }}$ Logarithm transformation of original value; ${ }^{\mathrm{b}}$ Standardized coefficients are reported. $* * * p<0.01, * * p<0.05, * p<0.10$ 